\title{
Effects of Gamma Irradiation on Microbiological, Phytochemical Content, Antioxidant Activity and Inhibition of Angiotensin Con- verting Enzyme (ACE) Activity of Peperomia pellucida (L.) Kunth
}

\author{
Abdul Mun'im ${ }^{1}$, Fitria Ramadhani ${ }^{1}$, Kartika Chaerani ${ }^{1}$, Lili Amelia ${ }^{2}$, Arif Arrahman ${ }^{3}$ \\ 'Department of Pharmacognosy-Phytochemistry, Faculty of Pharmacy, Universitas Indonesia, Depok-16424, INDONESIA. \\ ${ }^{2}$ Graduate Program of Herbal Medicine, Faculty of Pharmacy, Universitas Indonesia, Depok-16424, INDONESIA. \\ ${ }^{3}$ Department of Medicinal Chemistry, Faculty of Pharmacy, Universitas Indonesia, Depok-16424, INDONESIA.
}

\begin{abstract}
Objective: Gamma irradiation is an effective technique can be used to reduce contaminants in herbal products. Peperomia pellucida (L.) Kunth belongs to Piperaceae family has some biological activity, such as antioxidant and ACE inhibitor. The aimed of this research was to determine the effects of gamma irradiation on microbiological, phytochemical content, antioxidant and ACE inhibition activity. Methods: Sample was irradiated at a various dose of $0,2.5,5,7.5$ and $10 \mathrm{kGy}$. Microbiological was determined as total aerobic plate count (TAPC), and total yeast and mold (TYC), total phenolic content (TPC), total flavonoid content (TFC), antioxidant and ACE inhibition activity were investigated by various in vitro colorimetric methods. Results: Irradiation dose of $10 \mathrm{kGy}$ reduced TAPC and TYC. Irradiation dose of $10 \mathrm{kGy}$ slightly increased TPC, antioxidant, and ACE inhibition activity $(p<0.05)$ but reduced TFC significantly $(p<0,05)$ and caused degradation of flavonoids in this plant. Correlation analysis showed that phenolic compounds have a role as antioxidant and ACE inhibitor. Conclusion: gamma
\end{abstract}

irradiation was found to be sufficient to ensure microbiological safety, increase TPC, the antioxidant and ACE inhibitory activity but caused degradation of flavonoids on Peperomia pellucida (L.) Kunth.

Key words: ACE inhibitor, Antioxidant, Gamma irradiation, Microbiological, Peperomia pellucida (L.) Kunth, Total phenolic, Total flavonoid.

Correspondence :

Abdul Mun'im

Department of Pharmacognosy-Phytochemistry, Faculty of Pharmacy, Universitas Indonesia, Depok - 16424, INDONESIA.

Phone no: +62 217270031

Email: abdul.munim61@ui.ac.id

DOI: 10.5530/jyp.2017.1s.17

\section{INTRODUCTION}

Raw plant materials usually carry a great number of bacteria and fungi that come from the soil. The current process like harvesting, handling, storage, and production also can cause additional contamination and microbial growth. ${ }^{1}$ This can lead to a shorter shelf life and in some cases, it can cause disease. ${ }^{2}$ One way can be used to overcome this problem is decontamination process. Conventional decontamination by using heat and chemicals can reduce the bioactivity of herbal products. ${ }^{3}$ Gamma irradiation is an environmentally friendly technology that can be used to reduce contaminants in herbal products. ${ }^{2,3}$

Available reports have clearly demonstrated that exposure of food commodities to Gamma Irradiation. Exposure of gamma irradiation at 1.4 kGy on Ginkgo biloba (L.) and Paullinia cupana (HBK) reduced the numbers of microbial load, the number of yeast and mold without cause degradation of flavonoid and caffeine. ${ }^{1}$ Gamma irradiation on Pennisetum glaucum reduced microbial contamination as well as yeast and mold and didn't provide significant change in phenolic compounds. ${ }^{4}$

Peperomia pellucida (L.) Kunth belongs to Piperaceae family has activity as antioxidant and angiotensin converting enzyme (ACE) inhibitor. ${ }^{5,6}$ Ethanolic extract of this plants have ACE inhibitory activity with $\mathrm{IC}_{50}$ of $7.17 \mu \mathrm{g} / \mathrm{ml} .^{7}$ Phenolic compounds and flavonoids contained in this plant is reported to have antioxidant activity and ACE inhibitors. ${ }^{5,7}$

The aim of this research was to evaluate the effects of gamma irradiation in reducing microbia contamination, and also of antioxidant activity,
ACE inhibitor activity, total phenol content and total flavonoid content, as well as changes in the chemical components by thin layer chromatography profiling on Peperomia pellucida (L.) Kunth.

\section{MATERIALS AND METHODS}

\section{Chemicals and reagents}

Petri film aerobic count plate and Petri film yeast and mold count plate were purchased from 3M company (USA), Folin-Ciocalteu reagent (Merck, Germany), DPPH (2,2-diphenyl-1-picrylhydrazyl) (Wako, Japan), gallic acid (Sigma-Aldrich, USA), quercetin (Sigma-Aldrich, USA), captopril (Zhejiang Huahai Pharmaceutical, China) and ACE KitWST test kit (Dojindo Laboratories, Japan). All other reagents were of analytical reagent grade.

\section{Plants materials}

Peperomia pellucida (L.) Kunth was obtained from the Research Institute for Medicinal Plants and Aromatic (Balitro), Bogor, West Java, Indonesia. This plants packed hermetically in polyethylene bags (each $50 \mathrm{~g}$ ) before irradiation treatment and storage. These samples were irradiated using cobalt-60 as the source of irradiation to dose $2.5,5,7.5$, and $10 \mathrm{kGy}$ at the dose rate $7.290 \mathrm{kGy} / \mathrm{h}$. Irradiation was conducted at the Center for Isotope and Radiation Technology Applications (PATIR), National Nuclear Energy Agency (BATAN), Pasar Jumat, South Jakarta. 


\section{Microbiological analysis}

\section{Total Aerobic Count Plate (TAPC)}

TAPC were determined by using Petri film aerobic count plate method. Samples solution was prepared by diluting $1 \mathrm{~g}$ of dry samples then dissolved in $10 \mathrm{~mL}$ of saline solution as $10^{-1}$ dilution, and made dilutions $10^{-2}, 10^{-3}, 10^{-4}$ by using $1 \mathrm{ml}$ of diluents in $9 \mathrm{ml}$ saline solution. Top of the film was lifted, and then $1 \mathrm{ml}$ of each dilution samples were pipetted into the bottom of the film and then closed again. Samples were dispersed using the plastic spreader and let the film for 1 minute to for gel to solidity. Plate was incubated for 48 hours at a temperature of $35 \pm 1^{\circ} \mathrm{C}$ and count the number of bacterial colonies growing. ${ }^{8}$

\section{Total Yeast and Mold Count (TYC)}

TYC were determined by using Petri film yeast and mold count plate. The sample dilutions were prepared at the same as TAPC. The top of the film was lifted, and then $1 \mathrm{ml}$ of each dilution samples were pipetted into the bottom of the film and then closed again. Samples were dispersed using the plastic spreader and let the film for 1 minute to for gel to solidity. Plate was incubated for 5 days at a temperature of $25 \pm 1^{\circ} \mathrm{C}$ and count the number of bacterial colonies growing. ${ }^{9}$

\section{Preparation of extracts}

Dry powder of samples $(50 \mathrm{~g})$ were extracted by reflux method for 30 minutes using $500 \mathrm{ml}$ of $80 \%$ ethanol. The extract was concentrated by using rotary vacuum evaporator (Buchi, Switzerland) to give crude extracts. Extraction yield was calculated based on dry weight. Extracts were stored at $4^{\circ} \mathrm{C}$ until used.

\section{Determination of the total phenolic content (TPC)}

Total phenolic content was measured by Folin-Ciocalteu method. The extract $(25 \mathrm{mg}$ ) was diluted in $25 \mathrm{ml}$ of methanol, $0.5 \mathrm{ml}$ aliquot of diluted was mixed with $2.5 \mathrm{ml}$ of $10 \%$ Folin-Ciocalteu reagent, vortexed and incubated at $25^{\circ} \mathrm{C}$. After 2 minutes, $2 \mathrm{ml}$ of $7.5 \% \mathrm{Na}_{2} \mathrm{CO}_{3}$ was added. The mixture was vortex and incubated for 60 minutes at $25^{\circ} \mathrm{C}$. The absorbance of the mixture was measured at $765 \mathrm{~nm}$ with a UV-VIS spectrophotometer. ${ }^{10}$ Gallic acid was used as a reference standard, and the results were expressed as mg of gallic acid equivalents (GAE) per $g$ of the extract (mg GAE/g extract).

\section{Determination of the total flavonoid content (TFC)}

Total flavonoid content was measured using $10 \% \mathrm{AlCl}_{3}$ solution with slight modification. ${ }^{11}$ The extract $(25 \mathrm{mg}$ )was diluted in $25 \mathrm{ml}$ of methanol, $0.5 \mathrm{ml}$ aliquot of diluted was mixed with $1.5 \mathrm{ml}$ methanol, $0.1 \mathrm{ml}$ of $10 \% \mathrm{AlCl}_{3}, 0.1 \mathrm{ml}$ of $1 \mathrm{M}$ sodium acetate solution, and $2.8 \mathrm{ml}$ distilled water. The mixture was vortex and incubated for 30 minutes at $37^{\circ} \mathrm{C}$. The absorbance of the mixture was measured at $415 \mathrm{~nm}$ with a UV-VIS spectrophotometer. Quercetin was used as a reference standard, and the results were expressed as $\mathrm{mg}$ of quercetin equivalents (QCTE) per $\mathrm{g}$ of the extract (mg QCTE/g extract).

\section{Determination of free radical scavenging activity by the DPPH method}

Antioxidant activity was determined by using DPPH method. ${ }^{12,13}$ tanukimame Dry extract was dissolved in methanol with different concentrations. The sample $(1 \mathrm{ml})$ was reacted with $1 \mathrm{ml} \mathrm{DPPH}$ and $2 \mathrm{ml}$ methanol. The mixture was vortex and incubated in the dark for 30 minutes at $37^{\circ} \mathrm{C}$. The absorbance was measured with spectrophotometer at $515 \mathrm{~nm}$. Quercetin was used as a reference standard.

\section{Enzyme assay}

Dry extracts were dissolved in distilled water and made in a final concentration of $100 \mu \mathrm{g} / \mathrm{ml}$. Each extract was subjected to ACE inhibitory assay by using Dojindo ACE Kit-WST test kit as instructed in the manufacturer's protocol. ${ }^{14}$ This assay used 3-hydroxybutyrate glycyl glycylglycine (3HB-GGG) as substrate for screening of the ACE inhibitory. The absorbance value of the assay reaction was measured at $450 \mathrm{~nm}$ using microplate reader. Captopril was used as a positive control in this study.

\section{Thin layer chromatography (TLC) profile}

TLC profile was performed in thin layer chromatography method using silica plate as the stationary phase and dichloromethane-methanol (90:10) as eluent. TLC profile was analyzed using densitometer at wavelength of $254 \mathrm{~nm}$ and $366 \mathrm{~nm}$.

\section{Statistical analysis}

Data presented for TAPC, TYC, antioxidant activity, and ACE inhibition activity were obtained from triplicate measurements, and result was expressed as mean \pm standard deviation. The data were analyzed using one-way ANOVA followed Bonferroni and Tukey's posttest to assess significant differences $(\mathrm{p}<0.05)$ between the samples. Correlation between TPC, TYC, antioxidant activity, and ACE inhibition activity analyzed using Pearson correlation.

\section{RESULTS}

\section{Microbiological analysis}

Table 1 showed effect gamma irradiation on total aerobic plate count (TAPC) and total yeast count (TYC). In this study, gamma irradiation reduced the level of bacteria, yeast, and mold of the samples. TAPC was higher than TYC on all examined samples. The total microbial count was decreased while the increase of irradiation dose. There were no detected bacteria at doses $10 \mathrm{kGy}$, while at dose of $7.5 \mathrm{kGy}$ was enough to damage all yeast and mold in the sample.

\section{Determination of total phenolic content and total flavonoid content}

Table 2 showed the effect of gamma-irradiation on TPC and TFC of $P$. pellucida. Gamma-irradiation until $10 \mathrm{kGy}$ didnot change TPC, but interestingly the TFC exhibited a different result in contrast with TPC after irradiation. Comparing TFC of control with the gamma irradiated samples demonstrate that the gamma irradiated samples exhibited significantly lower TFC than the control

\section{Determination of DPPH free radical scavenging and ACE inhibitory activity}

Table 3 showed DPPH free radical scavenging and ACE inhibitory activity. DPPH free radical scavenging activity increased after gamma irradiation. Statistical results showed a significant increase in $\mathrm{IC}_{50}$ value by increased irradiation dose. Variation dose of gamma irradiation lead to differences in ACE inhibitory activity. Results of statistical analysis results showed a significant increase $(\mathrm{p}<0.05)$ on the inhibitory activity after irradiation up to a dose of $7.5 \mathrm{kGy}$, however at dose of $10 \mathrm{kGy}$, ACE inhibitory activity did not change significantly ( $p>0.05)$ compare to sample irradiated with a dose of $7.5 \mathrm{kGy}$.

\section{Thin layer chromatography (TLC) profile}

TLC profile of the P. pellucida extracts can be seen in Figure 1 and Figure 2. There is a reducing in the intensity of spot number 3 after gamma irradiation (Figure 2), and is accompanied by increasing intensity of spot 

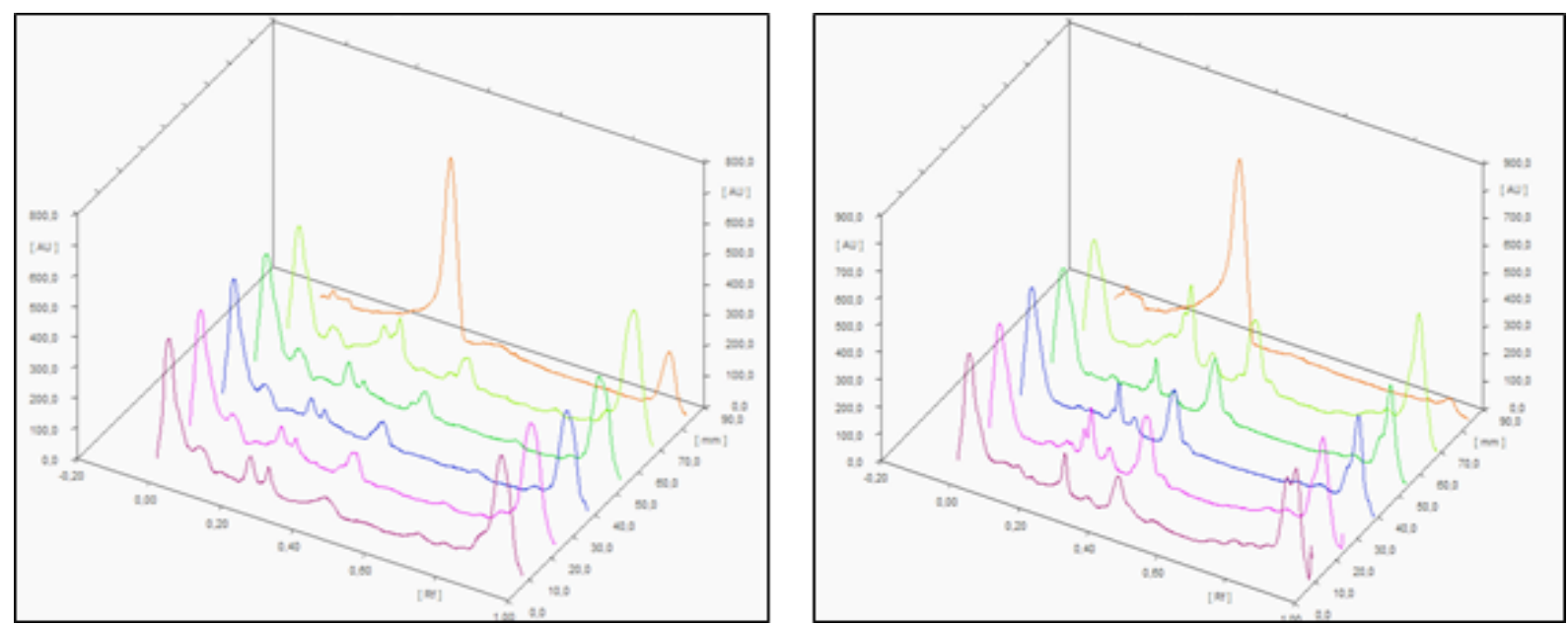

Figure 1: Thin layer chromatography profile of P. pellucida extract using densitometry (A) $254 \mathrm{~nm}$ wavelength (B) Wavelength $366 \mathrm{~nm}$.

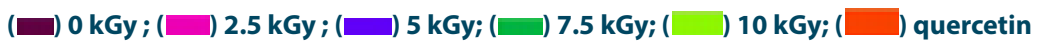
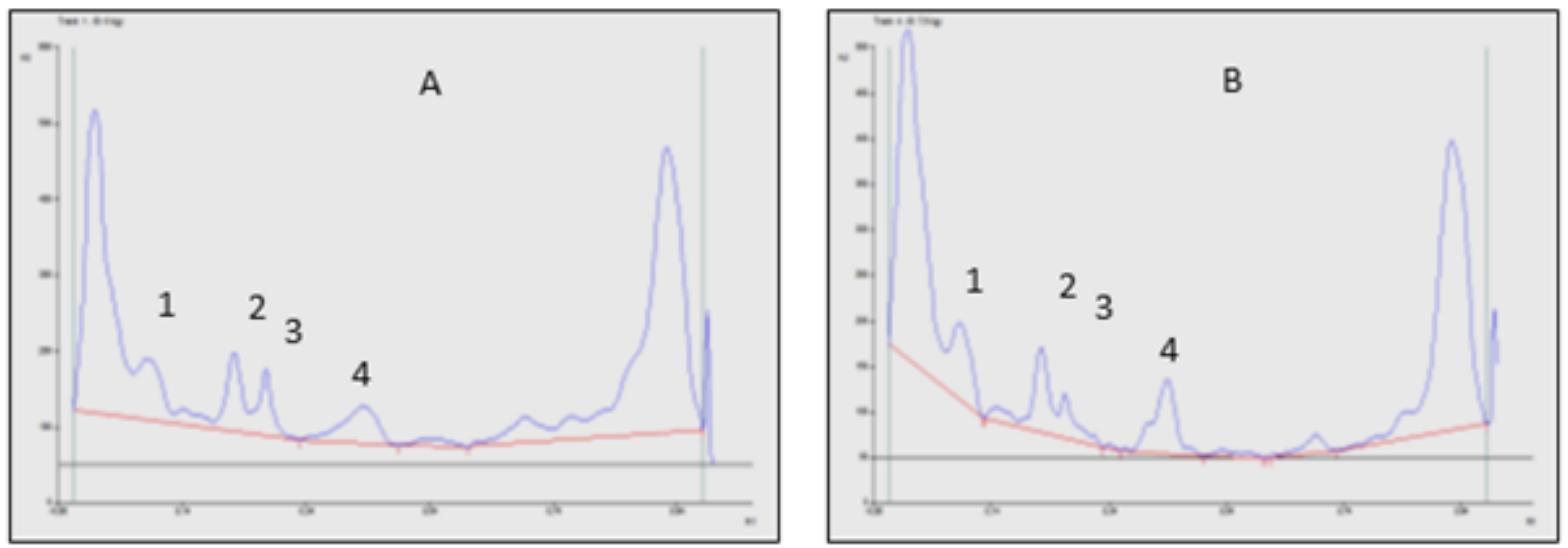

Figure 2: TLC profile of the P. pellucida extract with irradiation doses of (A) 0 kGy (B) 7.5 kGy.

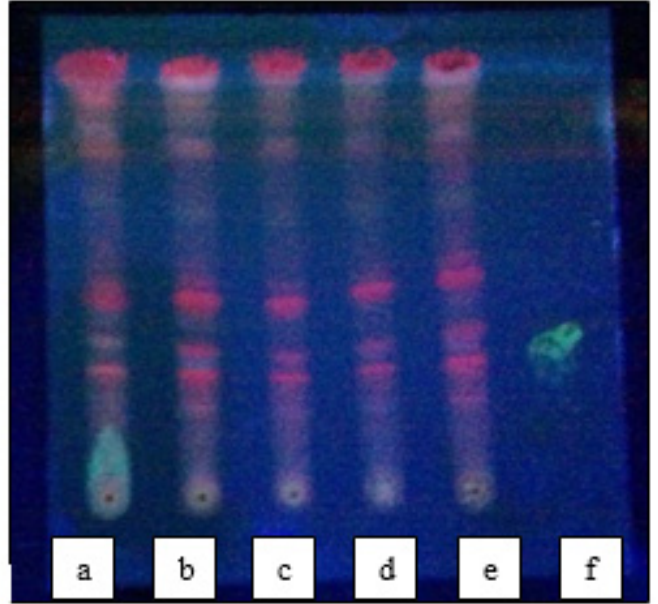

Figure 3: TLC profile after sprayed with $5 \% \mathrm{AICl} 3$ solution at wavelength of $366 \mathrm{~nm}$. (a) $0 \mathrm{kGy}$ (b) $2.5 \mathrm{kGy}$ (c) $5 \mathrm{kGy}$ (d) 7.5 kGy (e) 10 kGy (f) quercetin.

number 4. Figure 3 showed TLC plat after sprayed by $\mathrm{AlCl}_{3}$ reagent. Flavonoid was detected at non-irradiated extracts with strong intensity, while on the irradiated extracts spot flavonoid showed low intensity. This result corresponds with TFC after gamma irradiation.

\begin{tabular}{ccc}
\multicolumn{2}{c}{ Table 1: Microbial decontamination level } \\
\hline Irradiation dose & TAPC (CFU / g) & TYC (CFU/g) \\
\hline $0 \mathrm{kGy}$ & $5.3 \times 10^{5} \pm 0.42$ & $7.00 \times 10^{2} \pm 2.64$ \\
$2.5 \mathrm{kGy}$ & $7.7 \times 10^{4} \pm 0.07$ & $2.00 \times 10^{1} \pm 1.73$ \\
$5 \mathrm{kGy}$ & $3.35 \times 10^{4} \pm 0.21$ & $3.33 \pm 0.58$ \\
$7.5 \mathrm{kGy}$ & $2 \times 10^{2} \pm 0.00$ & $\mathrm{ND}$ \\
$10 \mathrm{kGy}$ & $\mathrm{ND}$ & $\mathrm{ND}$ \\
\hline
\end{tabular}

TAPC $=$ Total aerobic plate count, $\mathrm{TYC}=$ Total yeast count, values are presented as mean+SEM from triplicate experiments.

\section{DISCUSSION}

Gamma irradiation is one effective method to reduce microbial load, to maintain quality and safety, and to extend the shelf life of natural products. However, there are several reports on effect of irradiation on sec- 
Table 2: Total phenolic and total flavonoid content in P. pellucida after gamma-irradiation

\begin{tabular}{ccc}
$\begin{array}{c}\text { Irradiation dose } \\
(\mathrm{kGy})\end{array}$ & TPC (GAE mg / g extract) & $\begin{array}{c}\text { TFC (QCTE mg / g } \\
\text { extract) }\end{array}$ \\
\hline 0 & $26.29 \pm 0.34$ & $30.16 \pm 0.18$ \\
2.5 & $29.41 \pm 0.15^{*}$ & $25.09 \pm 0.14^{*}$ \\
5 & $31.46 \pm 0.15^{\star}$ & $28.47 \pm 0.14^{*}$ \\
7.5 & $34.41 \pm 0.532^{*}$ & $25.02 \pm 0.05^{*}$ \\
10 & $29.36 \pm 0.237^{\star}$ & $25.38 \pm 0.67^{\star}$ \\
\hline
\end{tabular}

Values are presented as mean \pm SEM from triplicate experiments, TPC $=$ total phenolic content, $\mathrm{GAE}=$ gallic acid equivalent, $\mathrm{TFC}=$ total flavonoid content, $\mathrm{QCTE}=$ quercetin equivalent, ${ }^{*}$ ) significantly different when compared with $0 \mathrm{kGy}$.

Table 3: DPPH free radical scavenging and ACE inhibitory activity of $\boldsymbol{P}$. pellucida extract after gamma-irradiation

\begin{tabular}{ccc}
\hline $\begin{array}{c}\text { Irradiation Dose } \\
(\mathrm{kGy})\end{array}$ & $\begin{array}{c}\text { DPPH free radical } \\
\text { scavenging activity } \\
(\mathrm{IC} \text { ppm) }\end{array}$ & $\begin{array}{c}\text { ACE inhibition Percentage } \\
\text { (\%) }\end{array}$ \\
\hline 0 & $244.92 \pm 0.65$ & $50.07 \pm 2.61$ \\
2.5 & $191.74 \pm 1.96^{*}$ & $59.70 \pm 4.07^{*}$ \\
5 & $174.81 \pm 0.72^{*}$ & $52.16 \pm 3.59$, \\
7.5 & $166.20 \pm 0.72^{*}$ & $63.71 \pm 3.17^{*}$ \\
10 & $188.67 \pm 0.75^{*}$ & $57.60 \pm 2.00$ \\
\hline
\end{tabular}

Values are average from triplicate experiments, ${ }^{*}$ ) significantly different when compared with $0 \mathrm{kGy}$.

ondary metobolites. In this study, the microbial count decreased while increasing of irradiation dose. Irradiation treatment damaged microbial cells by break down the DNA, photons induced the death of the organism and caused some organisms can not reproduce. ${ }^{4,15}$

There are several reports on effect of gamma irradiation on total phenolic content (TPC) and total flavonoid content (TFC). The gamma irradiation increased TPC in clove, nutmeg and skin of almond after irradiation. ${ }^{2,16}$ This increase may be caused by the degradation of tannins into a simple phenol compound which was contributed to increasing the total phenolic contents. ${ }^{17}$ Gamma irradiation is also known to increase the of phenylalanine ammonia lyase activity which is responsible for synthesized of polyphenol acid. ${ }^{18}$ In this study, irradiation decreased TFC. This decrease may be attributed to the change of flavonoid structure after irradiation that can't be extracted or not dissolve in the used solvent for the extraction. ${ }^{19}$ The previous study showed the different result in Centella asiatica, irradiation caused increasing TFC compared with the nonirradiated. ${ }^{20}$

Polyphenols have been known to be responsible for the antioxidant activity of the products. Their free radical scavenging activity via electron donation to DPPH radical. The previous study reported that antioxidants activity of oat $\beta$-glucan increase by increasing irradiation dose. ${ }^{10} \mathrm{On}$ the polysaccharides, like ergosan reported that antioxidant activity increased with increasing irradiation dose. ${ }^{21}$ Increasing of the antioxidant activity may be caused due to fragmentation of hydroxyl group from the sample, hydrogen atoms reacted with free radical, and they convert it into a more stable product. ${ }^{22}$

In the previous studies reported that the gamma irradiation treatment caused degradation of phenolic compounds with large into small mol- ecule of phenolic compounds. ${ }^{23,24,25}$ In another study, irradiation treatment caused degradation of tannin into phenolic compounds, so that total phenolic contents increased in the extract. ${ }^{17}$ The increasing in total phenolic content is believed to cause an increasing in the inhibition of ACE activity. Phenolic compounds have been reported to have efficacy as angiotensin converting enzyme inhibitor. ${ }^{7,26,27} \mathrm{ACE}$ is a dipeptidyl carboxypeptidase with $\mathrm{Zn}$ metal in the active site, free $\mathrm{OH}$ groups of phenolic compounds form chelates with $\mathrm{Zn}$ ion, causing ACE becomes inactive. ${ }^{26}$ But, further investigation is needed to confirm this speculation.

This because treatment of gamma irradiation up to $10 \mathrm{kGy}$ caused degradation of chemical components of the extracts and the degradation of product likely join the subsequent spot thus causing the rise the other spots intensity. ${ }^{28}$ It can be concluded that irradiation treatment caused degradation of flavonoids on P.pellucida. Similarly, the amount of total flavonoids in Amygdalus communis was decreased after irradiation treatment. ${ }^{24}$

In this study, there is correlation between DPPH free radical scavenging activity with total phenol content $(r=-0.903 ; p<0.05)$. These results are consistent with the strong correlation between TPC and antioxidant activity in Pomegranate peels. ${ }^{17} \mathrm{TFC}$ and $\mathrm{IC}_{50}$ of sample showed that there is no correlation between TFC and $\mathrm{IC}_{50}$ of samples $(\mathrm{r}=0.687, \mathrm{p}=0.05)$. This indicated that flavonoid in the sample doesn't provide DPPH free radical scavenging activity.

ACE inhibition activity also correlated with TPC ( $p<0.05, r=0.608)$, similarly correlation between TPC and ACE inhibition Centella asiatica. ${ }^{29}$ The ACE inhibition activity showed significant correlation with TFC $(p<0.05)$ but has negative correlation $(r=-0.805)$. This result suggested that non-flavonoid compound plays a role as ACE inhibitor.

\section{CONCLUSION}

The result of this study indicated that gamma irradiation doses up to $10 \mathrm{kGy}$ were found to be sufficient to ensure the microbiological safety of Peperomia pellcida. Gamma irradiation increase TPC, the antioxidant and ACE inhibitory activity, but caused degradation of flavonoids on Peperomia pellucida (L.) Kunth.

\section{ACKNOWLEDGEMENT}

This study was supported by the Ministry of Research and Technology, Republic of Indonesia and Directorate of Research and Community Engagement, Universitas Indonesia via Hibah PITTA 2016.

\section{CONFLICTS OF INTEREST}

There are no conflicts of interest.

\section{ABBREVIATIONS USED}

TAPC: Total Aerobic Count Plate; TYC: Total Yeast and Mold Count; TPC: Total Phenolic Content; TFC: Total Flavonoid Content; ACE: Angiotensin Converting Enzyme.

\section{REFERENCES}

1. Soriani RR, Satomi LC, Pinto TDJA. Effects of ionizing radiation in ginkgo and guarana. Radiat Phys Chem. 2005;73(4):239-42. https://doi.org/10.1016/j.radphyschem.2005.01.003.

2. Chatterjee S, Kumar V, Khole S, Sanyal B, Murali TS, Variyar PS. Radiation processing: An effective quality control tool for hygienization and extending shelf life of a herbal formulation, Amritamehari churnam. J Radiat Res Appl Sci. 2015;9(1):86-95. https://doi.org/10.1016/j.jrras.2015.09.007.

3. Kumar S, Gautam S, Powar S, Sharma A. Microbial decontamination of medicinally important herbals using gamma radiation and their biochemical characterisation. Food Chem. 2010;119(1):328-35. https://doi.org/10.1016/j.foodchem.2009.06.034

4. Maha BM, Bousselmi M, JerbiT, Ben N, Fattouch S. Gamma radiation effects on 
microbiological, physico-chemical and antioxidant properties of Tunisian millet (Pennisetum glaucum). Food Chem. 2014;154:230-7. https://doi.org/10.1016/j. foodchem.2014.01.015; PMid:24518337.

5. Pappachen LK, Chacko A. In-vitro antioxidant activity and determination of total phenolic, flavonoid contents of Peperomia pellucida Linn. Am J Pharm Heal Res. 2013;1(7):99-101.

6. Saputri FC, Mun'im A, Lukmanto D, Aisyah SN, Rinandy JS. Inhibition of angiotensin converting enzyme (ACE) activity by some Indonesia edible plants. Int J Pharm Sci Res, 2015;6(3):1054-9.

7. Balasuriya BWN, Rupasinghe HPV. Plant flavonoids as angiotensin converting enzyme inhibitors in regulation of hypertension. Funct Foods Heal Dis, 2011;1(5):172-88.

8. AOAC. Aerobic Plate Count in Food: Dry rehydratable film. AOAC International. 1994.

9. AOAC. Yeast and Mold Counts in Foods Dry rehydratable film method. AOAC International. 2000.

10. Shah M, Kabir H, Hossain MM, Kabir I, Rahman M, Hasanat A. $\alpha$-Amylase inhibition and cytotoxic activities of ethanol extract of Steudnera colocasiifolia K. Koch leaves. J Young Pharm. 2016;8(4):391-7. https://doi.org/10.5530/ jyp.2016.4.15.

11. Pervin R, Afrin S, Sabrin F, Zohora US, Rahman MS, Islam KD. Antioxidant, antibacterial and brine shrimp lethality bioassay of Amoora cucullata, a mangrove plant. J Young Pharm 2016;8(1):33-8. https://doi.org/10.5530/jyp.2016.1.8.

12. Agarwal K, Varma R. Antioxidant ability of some common Indian vegetables. J Young Pharm. 2015;7(3):262-6. https://doi.org/10.5530/jyp.2015.3.18.

13. Mun'im A, Negishi O, Ozawa T. Antioxidative compounds from Crotalaria sessiliflora. Biosci Biotechnol Biochem. 2003;67(2):410-4. https://doi.org/10.1271/ bbb.67.410 ; PMid:12729010.

14. Dojindo ACE Kit-WST (100): Technical Manual. Japan: Dojindo Molecular Technologies, 2013.

15. Jose A, Balasubramanian R, Thomas D, Balakrishnan A, Aiyalu R. Alcoholic extract of Wrightia tinctoria leaves and isolates there of afford DNA protection in post irradiated Sprague Dawley rats. JYoung Pharm. 2016;8(4):398-405. https:// doi.org/10.5530/jyp.2016.4.16

16. Harrison K, Were LM. Effect of gamma irradiation on total phenolic content yield and antioxidant capacity of Almond skin extracts. Food Chem. 2007;102(3):9327. https://doi.org/10.1016/j.foodchem.2006.06.034.

17. Mali AB, Khedkar K, Lele SS. Effect of gamma irradiation on total phenolic content and in vitro antioxidant activity of Pomegranate (Punica granatum L.) peels. Food Nutr Sci. 2011;2(5):428-33. https://doi.org/10.4236/fns.2011.25060.

18. Ghadi FE, Ghara AR, Ghanbari T. Effect of gamma irradiation on the total phe- nolic content and free radical-scavenging activity of Iranian date palm Mazafati (Phoenix dactyfera L.). Int J Latest Res Sci Technol. 2015;4(5):149-53.

19. Verma M, Sharma P, Gour VS, Kothari SL. Moisture-mediated effects of $\gamma$-irradiation on antioxidant properties of mung bean (Vigna radiate $L$.) cultivars. Innov Food Sci Emerg Technol [2016;34:59-67. https://doi.org/10.1016/j. ifset.2016.01.012.

20. Moghaddam SS, Jaafar $H$, Ibrahim R, Rahmat A. Effects of acute gamma ir radiation on physiological traits and flavonoid accumulation of Centella asiatica. Molecules 2011;16(6):4994-5007. https://doi.org/10.3390/molecules16064994 ; PMid:21694666.

21. Heidarieh M, Borzouei A, Rajabifar S, Ziaie F, Shafiei S. Effects of gamma irradiation on antioxidant activity of Ergosan. Iran J Radiat Res. 2012;9(4):245-9.

22. Shah A, Masoodi FA, Gani A, Ashwar BA. Effect of $\gamma$-irradiation on antioxidant and antiproliferative properties of oat $\beta$-glucan. Radiat Phys Chem. 2015;117:120-7. https://doi.org/10.1016/j.radphyschem.2015.06.022.

23. Khattak KF, Simpson TJ, Ihasnullah. Effect of gamma irradiation on the extraction yield, total phenolic content and free radical-scavenging activity of Nigella sativa seed. Food Chem. 2008;110(4):967-72. https://doi.org/10.1016/j.foodchem.2008.03.003; PMid:26047287.

24. Moosavi KS, Hosseini S, Dehghan G, Jahanban-esfahlan A. The effect of gamma irradiation on phytochemical content and antioxidant activity of stored and none stored Almond (Amygdalus communis L.) Hull. Pharm Sci. 2014;20(3):102-6.

25. Taheri S, Abdullah TL, Karimi E, Oskoueian E. Antioxidant capacities and total phenolic contents Enhancement with acute gamma irradiation in Curcuma alismatifolia (Zingiberaceae) leaves. Int J Mol Sci. 2014;15(7):13077-90. https://doi. org/10.3390/ijms150713077; PMid:25056545 PMCid:PMC4139892.

26. Oboh G, J A, Akinyemi, Ademiluyi AO. Inhibitory effect of phenolic extract from Garlic on angiotensin-1 converting enzyme and Cisplatin induced lipid peroxidation- In vitro. Int J Biomed Sci. 2013;9(2):98-106. PMid:23847460 PMCid:PMC3708274

27. Ojeda D, Jiménez-ferrer E, Zamilpa A, Herrera-arellano A, Tortoriello J, Alvarez $\mathrm{L}$. Inhibition of angiotensin convertin enzyme (ACE) activity by the anthocyanins delphinidin- and cyanidin-3- O-sambubiosides from Hibiscus sabdariffa. J Ethnopharmacol. 2010;127(1):7-10. https://doi.org/10.1016/j.jep.2009.09.059; PMid:19808084.

28. Katrin $\mathrm{E}$, Winarno $\mathrm{H}$. Chromatogram profiles and cytotoxic activity of irradiated Mahkota Dewa (Phaleria macrocarpa (Scheff.) Boerl) leaves. Atom Indonesia. 2011;37(1):17-23. https://doi.org/10.17146/aij.2011.71.

29. SP L, Hadira O. In vitro inhibitory potential of selected Malaysian plants against key enzymes involved in hyperglycemia and. Malays J Nutr. 2011;17(1):77-86. PMid:22135867

Article History: Submission Date: 19-12-16; Revision Date:31-12-16; Accepted Date:27-01-17.

Cite this article: Mun'im A, Ramadhani F, Chaerani K, Amelia L, Arrahman A. Effects of Gamma Irradiation on Microbiological, Phytochemical Content, Antioxidant Activity and Inhibition of Angiotensin Converting Enzyme (ACE) Activity of Peperomia pellucida (L.) Kunth. J Young Pharm. 2017;9(1)Suppl:s65-s9. 